\title{
KONSEP ACTIVE LIVING DALAM PERANCANGAN JALUR PEDESTRIAN \\ Studi Kasus: Jalan L. L. R. E. Martadinata (Riau), Bandung, Jawa Barat
}

\author{
Christianto Hendrawan ${ }^{1 *}$, Yohanes Basuki Dwisusanto ${ }^{2}$ \\ ${ }^{1}$ Magister Arsitektur, Program Pascasarjana, Universitas Katolik Parahyangan \\ Jl. Merdeka no. 30, Bandung, Jawa Barat \\ ${ }^{2}$ Fakultas Teknik, Jurusan Arsitektur, Universitas Katolik Parahyangan \\ Jl. Ciumbuleuit no. 94, Bandung, Jawa Barat \\ "Email: chris_b18@yahoo.com
}

\begin{abstract}
Abstrak
Saat ini terdapat tren perancangan kota dengan konsep active living yang membuat penduduk kota menjadi lebih aktif bergerak, secara keseluruhan menjadikan kota lebih sehat (healthy city). Konsep active living ini salah satunya terdapat dalam jalur pedestrian kawasan komersial kota, yang berpotensi mewadahi lingkungan gerak aktif bagi penduduk kota. Toko-toko yang dirangkai berdekatan dapat membuat pejalan kaki aktif menelusuri kawasan secara keseluruhan. Tujuan dari jurnal ini adalah untuk mengetahui sejauh mana konsep active living telah diterapkan dalam jalur pedestrian Jalan L. L. R. E Martadinata (Jalan Riau). Dengan mengetahui kondisi lingkungan binaan untuk gerak aktif, diharapkan jurnal ini dapat menjadi bahan pertimbangan untuk perancangan jalur pedestrian di waktu kedepan, untuk kota yang lebih sehat. Metode pembahasan dilakukan dengan menganalisa masalah, peluang, kelebihan, dan kekurangan ruang gerak aktif yang muncul dalam jalur pedestrian di kawasan studi, bersinergi dengan studi literatur mengenai active living dalam lingkungan binaan. Dalam pengamatan, didapati bahwa jalur pedestrian dalam kawasan belanja jalan L. L. R. E. Martadinata belum sepenuhnya mewadahi gerak aktif. Jalur pedestrian menjadi kurang nyaman bagi pejalan kaki untuk bergerak bebas berbelanja dari pintu ke pintu. Terdapat value yang hilang dimana penduduk lebih memilih untuk menggunakan kendaraan bermotor untuk bergerak dari pintu ke pintu pertokoan.
\end{abstract}

Kata kunci: active living, kesehatan, jalur pedestrian, kawasan komersial

\begin{abstract}
Title: Active Concept in Pedestrian Design

In recent times, there's an active living design trend in cities around the world, giving chances for people to actively move inside the city, making city healthier. Active Living can occur within pedestrian way along shopping street corridor which has potential to move shoppers from one store to another through walking. Pedestrian way along shop corridor are potentially attractive for people move around inside the city. The purpose of this study is to give us information about how far active living concept has been implemented within L. L. R. E. Martadinata street. The information and analysis can be use for further development in pedestrian way design. Our study conducted through analyzing existing active design problems along with literature studies about active living in design.

Within the study, we conclude that L. L. R. E. Martadinata Street hasn't quite well providing active living movement for shopping street pedestrian way. Pedestrian way has become uncomfortable, for people to walk from store to store within street corridor. There's a missing value about active living, where people rather use automobile than actively moving along street corridor.
\end{abstract}

Keywords: active living, health, pedestrian way, commercial area 


\section{Pendahuluan}

Jan Gehl (2010) menyebutkan bahwa terdapat fenomena peningkatan penggunaan kendaraan bermotor dalam jumlah yang besar sejak dekade 1960an, mengurangi pergerakan aktif manusia dalam ruang kota. Invasi kendaraan yang semakin banyak ini mengurangi kualitas hidup dalam kota, dimana di dalamnya kualitas kesehatan turut turun. Kualitas ini semakin turun oleh perencanaan lingkungan binaan yang mengutamakan ruang untuk kendaraan bermotor mengurangi ruang untuk bergerak manusia aktif.

WHO pada tahun 2008 menyimpulkan bahwa terdapat kurang lebih 3.2 juta kematian per tahun sebagai akibat kurangnya aktivitas fisik (http://www.who.int/hia/green_economy len/ diakses pada Desember 2008). Hubungan antara kurangnya gerak aktif dan masalah kesehatan tercatat dengan jelas, termasuk di dalamnya obesitas, diabetes tipe 2, penyakit jantung, dan penyakit-penyakit kronis lainnya. Kita sedang melihat peningkatan masalah kesehatan publik karena populasi dalam jumlah yang besar sudah terbiasa dengan kendaraan bermotor, menyediakan transportasi langsung dari pintu ke pintu. Centers for Disease Control and Prevention (1996) menyebutkan bahwa konsep Active Living memberi kesempatan untuk penduduk kota bergerak secara fisik dalam kehidupan sehari - hari. Mendukung pernyataan tersebut, Jan Gehl (2010) menegaskan bahwa kota yang sehat di dalamnya memiliki pergerakan aktif, seperti berjalan kaki atau bersepeda sebagai pola pergerakan alami dalam kehidupan sehari-hari. Untuk masa depan kota yang lebih sehat, maka saat ini terdapat urgensi untuk menata lingkungan binaan yang lebih mewadahi gerak fisik aktif, melalui konsep Active Living.

Majalah Parks and Recreation (Maret 2003) menjelaskan bahwa dengan membangun dan merancang lingkungan gerak yang aktif (Active Living) adalah salah satu cara menyediakan peluang untuk aktivitas fisik rutin yang lebih banyak. Dalam lingkungan Active Living, individu tidak perlu berencana untuk melakukan aktivitas fisik, namun dengan sendirinya aktivitas ini telah diwadahi dalam lingkungan sekitarnya. Dengan kata lain, kesempatan untuk bergerak aktif telah tersedia ketika individu keluar dari pintu rumah, sekolah, atau kantor.

Jalur pedestrian adalah wadah gerak sirkulasi bagi penduduk kota. Hamid Shirvani (1985) menjelaskan bahwa jalur pedestrian/sidewalks berfungsi sebagai sarana sirkulasi dapat membentuk, mengontrol, mengarahkan pola aktivitas serta perkembangan kota, maka dengan merancang pedestrian dalam ruang publik dengan konsep active living, kita dapat membawa kota ke arah yang lebih baik, termasuk membuat penduduk lebih sehat.

Jalur pedestrian pada kawasan komersial pertokoan merupakan rangkaian jalur yang berpotensi mewadahi lingkungan gerak aktif bagi penduduk kota. Tokotoko yang dirangkai berdekatan dapat membuat pejalan kaki aktif menelusuri kawasan secara keseluruhan. Proses penelusuran ini tentu diwadahi oleh sebuah ruang khusus bernama jalur pedestrian.

Objek studi dalam jurnal ini adalah koridor jalan L. L. R. E. Martadinata (Jalan Riau). Jalan Riau memiliki 
potensi 'series of hubs' berupa kavling kavling aktivitas komersial sebagai modal dasar ruang gerak aktif. Menurut Spreiregen (1965), integrasi dan koordinasi beragam aktivitas merangkai suatu linkage dalam suatu kawasan. Pola-pola aktivitas pada kota-kota besar ada sebagai sebuah "seri-seri titik berhenti/series of hubs", dimana banyak dari titik-titik tersebut jelas lokasinya dan dapat dicapai melalui berjalan kaki dari satu titik ke titik lain.

Dalam pengamatan, didapati bahwa jalur pedestrian dalam kawasan belanja jalan L. L. R. E. Martadinata belum sepenuhnya mewadahi gerak aktif dalam jalur pedestrian. Terdapat inkonsistensi lebar jalan, elemen-elemen fisik dan spatial yang mengganggu proses berjalan kaki serta persinggungan dengan kendaraan bermotor yang membuat pengalaman berjalan kaki menjadi tidak nyaman.

Permasalahan yang muncul dari fenomena yang ada saat ini dapat diidentifikasi sebagai adanya peningkatan masalah kesehatan dalam kota karena kurangnya pergerakan aktif. Selain itu, perancangan lingkungan binaan yang kurang memberi kesempatan bagi penduduk untuk bergerak aktif dalam ruang kota, khususnya di Jalan L. L. R. E Martadinata. Tujuan dibuatnya jurnal ini adalah untuk mengetahui sejauh mana konsep active living telah diterapkan dalam jalur pedestrian Jalan L. L. R. E Martadinata (Jalan Riau). Dengan mengetahui kondisi lingkungan binaan untuk gerak aktif, diharapkan jurnal ini dapat menjadi bahan pertimbangan untuk perancangan jalur pedestrian di waktu kedepan, untuk kota yang lebih sehat.

\section{Implementasi Active Living Dalam Jalur Pedestrian}

Gerak aktif paling sederhana untuk menunjang transportasi di dalam kota adalah berjalan kaki. Berjalan kaki membutuhkan suatu wadah ruang, dinamakan jalur pedestrian. Menurut Danisworo (1991), pedestrian berasal dari bahasa Yunani, pedos, yang berarti berjalan kaki. Pedestrian berakar dari kata pedesterpedestris yang berarti orang yang berjalan kaki. Pedestrian juga dapat diartikan sebagai pergerakan, sirkulasi, atau perpindahan manusia dari satu titik asal ke tempat lain sebagai tujuan dengan berjalan kaki.

Berjalan kaki lebih dari sekedar perpindahan linear dari satu tempat ke tempat lain. Pejalan kaki dapat berhenti untuk berganti arah, bermanuver, mempercepat langkah, memperlambat langkah atau berganti ke aktivitas lain seperti duduk, berlari, berbaring, berdansa. Lebih dari sekedar transportasi, proses berjalan kaki menangkap kehidupan di dalam kota, seperti Jan Gehl (2010) katakan, "life happens on foot".

\section{Walkabilitas Pejalan Kaki}

Secara umum, setiap manusia memiliki batas kemampuan fisik. Proses berjalan kaki juga memiliki batas karena merupakan aktivitas fisik. Batas ini memiliki parameter yang dinamakan walkabilitas. Charlier (2009) mengatakan bahwa Walkabilitas merupakan sebuah kata sifat yang menunjukkan seberapa ramah lingkungan binaan dari suatu pedestrian dan seberapa mudah pejalan kaki dapat melakukan perjalanannya melalui jalur pedestrian. 
Kawasan dengan tata guna lahan yang bervariasi dan terhubung dengan jalan utama dan sarana-sarana trasnportasi umum memberikan peluang lebih besar kepada warga kota untuk tinggal, bekerja, bermain, berolahraga, berbelanja, dan memenuhi kebutuhan lainnya dengan berjalan kaki (Farr. 2008:129). Radius 500 meter merupakan patokan ideal untuk besar kawasan dengan jarak tempuh yang pas/cocok bagi para pejalan kaki dan memiliki toleransi besaran yang terbatas pada (Gehl. 2010):

a. $400-500$ meter atau 5-6 menit ke pusat kota/titik pusat kawasan;

b. $800-1000$ meter atau $10-12$ menit ke stasiun/layanan transportasi umum.

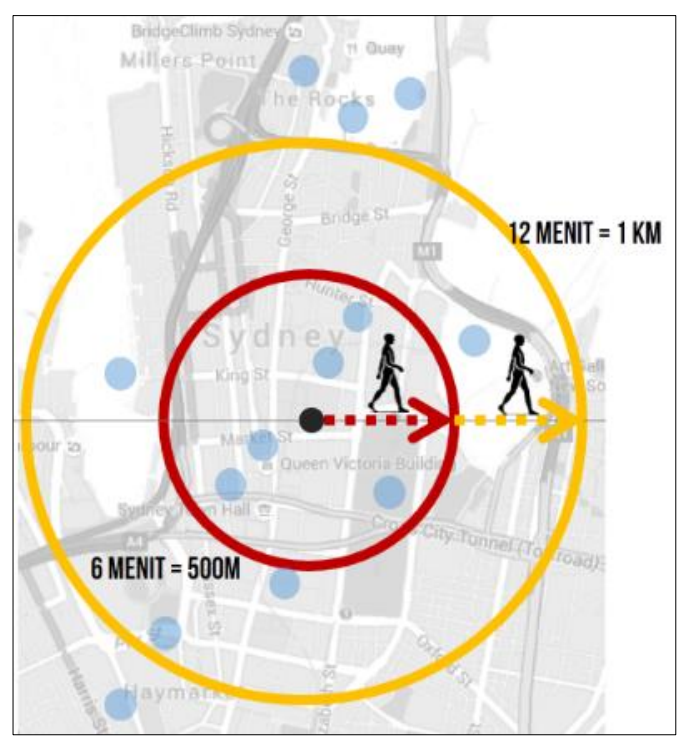

Gambar 1. Contoh besaran kawasan terhadap walkabilitas pejalan kaki

Digambar ulang menurut Gehl. 1987

\section{Zona Dalam Jalur Pedestrian}

Menurut Urban Street Design Guide, lebar jalur pedestrian sendiri terbagi menurut 4 zona. 4 Zona ini membagi 4 jenis aktivitas yang terjadi di dalam jalur pedestrian, dan memberi kesempatan pejalan kaki untuk menikmati jalur pedestrian dengan baik. Adapun zona zona tersebut yaitu:

\section{Frontage Zone}

Zona ini merupakan ruang interaksi antara pengguna jalur pedestrian dengan fungsi bangunan. Rangkaian frontage zone yang ditata baik akan mengundang pejalan kaki bergerak masuk ke dalam fungsi bangunan. Terdapat akses langsung dari frontage zone menuju fungsi bangunan yang memberi kontinuitas gerak dari jalur pedestrian ke dalam bangunan.

\section{Pedestrian Through Zone}

Zona ini merupakan jalur gerak lalu - lalang bagi pejalan kaki. Zona ini memberi kebebasan bagi pejalan kaki untuk berjalan tanpa interupsi berarti dari kendaraan bermotor. Selain untuk pejalan kaki, zona ini juga harus dapat dilalui oleh penyandang disabilitas.

\section{Street Furniture/Curb Zone}

Zona ini memberi ruang untuk optional activities seperti duduk, beristirahat, berorientasi. Street Furniture disediakan dalam zona ini untuk menunjang optional activities. Setiap Street Furniture diletakkan dengan maksud meningkatkan frekuensi dan durasi berjalan kaki.

Zona ini dapat diperluas (curb extension) dengan memakai area on street parking, pada titik-titik padat aktivitas, sehingga pejalan kaki memiliki lebih banyak ruang dan ragam aktivitas. 


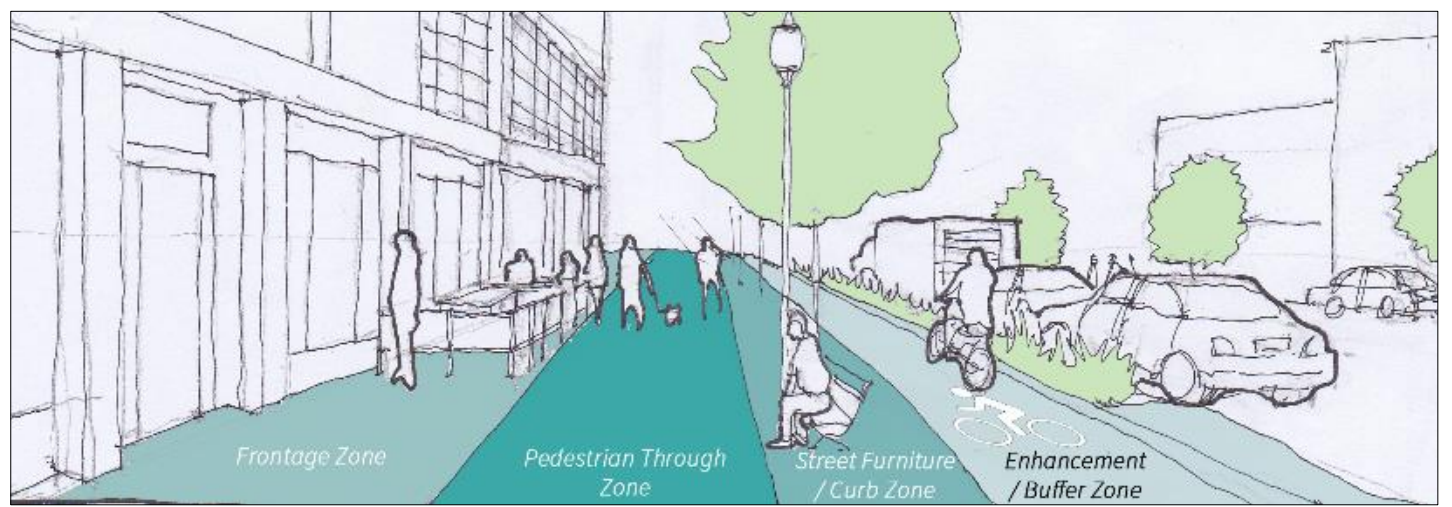

Gambar 2. Zona dalam pedestrian mewadahi beragam aktivitas, dari muka bangunan sampai batas jalan

Digambar ulang menurut Urban Street Design Guide, 2013

\section{Enhancement/Buffer Zone}

Zona ini merupakan ruang perantara yang memisahkan area pejalan kaki dengan area kendaraan bermotor. Bentuk dari zona ini dapat berupa area tanaman, area on street parking, atau zona sepeda. Buffer Zone ini juga berguna meningkatkan intensitas jumlah pejalan kaki karena memberi rasa aman.

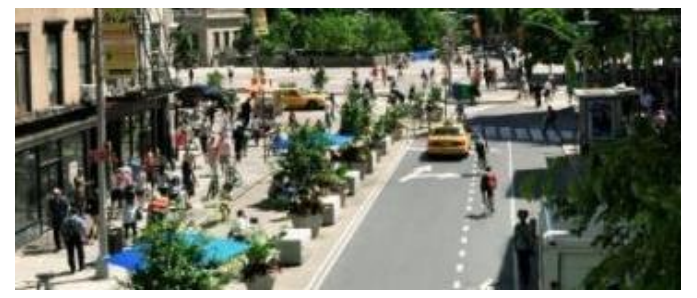

Gambar 3. Zona ruang dalam jalur pedestrian memberi kebebasan dan kenyamanan bagi pejalan kaki. Foto Jalur Pedestrian di Broadway, Manhattan

Sumber: www.pps.org, pada 1 November 2016

\section{TOD (Transit Oriented Development)}

Transportasi publik yang baik adalah bagian vital dari kota yang walkable. Penduduk yang tinggal di kota pasti ingin akses ke semua hal yang disediakan oleh kota. Jika mayoritas tempat tujuan utama kota tidak bisa dicapai dengan nyaman melalui transportasi umum, maka penduduk akan membeli kendaraan pribadi, lalu kota akan berakhir menjadi kota untuk kendaraan pribadi.

DeBourdeaudhuij (2003) mengatakan kita dapat meningkatkan kuantitas gerak aktif dengan memperbaiki akses menuju tempat transit publik.

Riset menunjukkan bahwa terdapat hubungan antara akses transit publik dengan gerak

aktif, dimana transit biasanya melibatkan gerak jalan kaki menuju perhentian kendaraan umum.

Perjalanan dari satu tempat ke stasiun transit adalah pengalaman active living. Dalam TOD yang compact, di dalamnya terdapat rangkaian perjalanan dengan walkabilitas dan kualitas ruang yang baik. Jika kita memperbanyak akses ke transportasi umum yang baik dan menarik maka peluang kegiatan active living dalam ruang publik semakin besar. Menurut pedoman Active Design Guidelines, terdapat beberapa kriteria mengenai halte transit kendaraan umum yang berhubungan dengan gerak aktif, yaitu:

a. Perletakkan halte transit terletak dekat dengan pintu masuk bangunan penting dalam kawasan untuk menarik pengguna dan memudahkan orientasi; 
b. Perletakkan halte transit ada dalam lingkungan jalan yang terhubung dengan baik satu dengan yang lainnya;

c. Halte memiliki informasi mengenai peta, jarak tempuh antar halte transit, waktu, dan informasi lainnya;

d. Halte perhentian memberi fasilitas yang mendukung kenyamanan berjalan kaki.
Dalam perletakkan halte, terdapat beberapa ruang yang menjadi perhatian. Pertama, terdapat ruang khusus untuk jalur kendaraan umum berhenti, sehingga tidak mengganggu arus lalu lintas. Kedua, terdapat bagian khusus dari jalur pedestrian yang digunakan untuk halte, sehingga posisi halte tidak mengganggu arus jalur pejalan kaki.

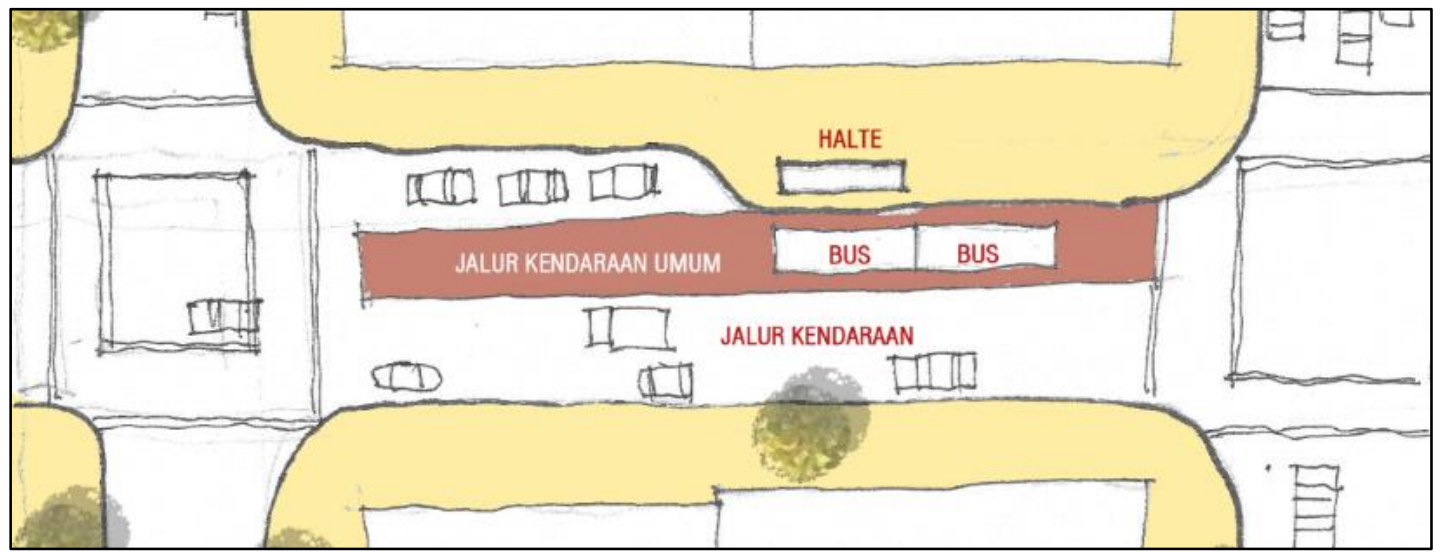

Gambar 4. Zona ruang di sekitar perletakkan halte

Digambar ulang menurut Active Design Guidelines, Promoting Phyisical Activity and Health in Design, 2010

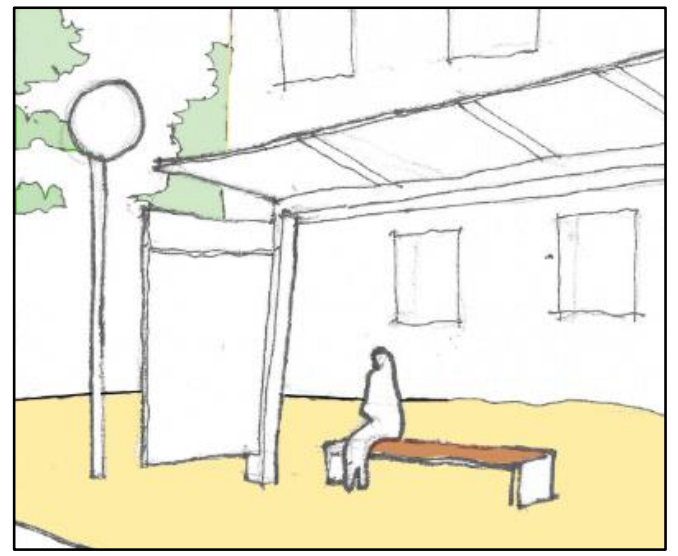

Gambar 5. Halte menyediakan kenyamanan bagi pejalan kaki

Sumber : Dokumentasi Pribadi Pada November 2016
Jalan L. L. R. E. Martadinata (Jalan Riau) Sebagai Wadah Berjalan Kaki Koridor jalan Riau marak dikunjungi karena memiliki ragam fungsi di dalamnya, seperti fungsi admnistrasi pemerintahan, fasilitas pendidikan, fasilitas perbelanjaan dan kuliner. Area yang menjadi fokus dari usulan desain ini adalah koridor jalan Riau sebelah Barat, berbatasan dengan jalan Ir. $\mathrm{H}$ Djuanda dan Jalan Lombok - Jalan Citarum. Kawasan ini padat dengan fungsi pertokoan belanja dan kuliner. 

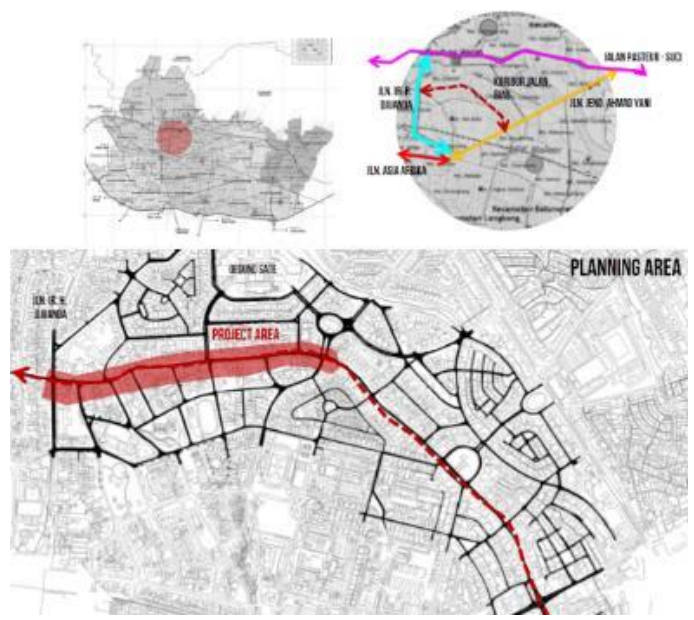

Gambar 6. Lokasi kawasan studi

Sumber: Dok. Pribadi pada 1 November 2016

Karakter Jalur Pedestrian Di Dalam Kawasan Studi

Jalur pedestrian di jalan Riau memiliki beberapa karakter yang berbeda. Berdasarkan karakter, jalur pedestrian terbagi menjadi 4 jenis yang memiliki karakter spatial masing-masing.

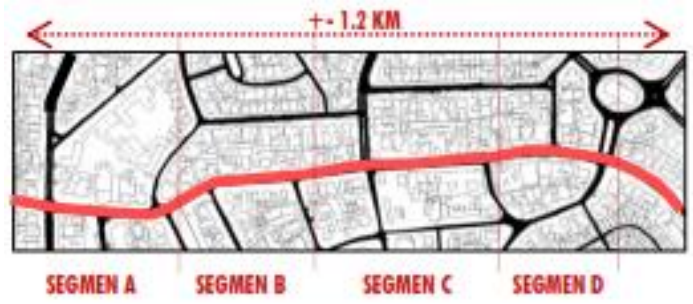

Gambar 7. Pembagian segmen berdasarkan karakter dalam kasus studi

Sumber: Dok. Pribadi pada 1 November 2016

Karakter dilihat dari pengalaman berjalan kaki di dalam kawasan, bukan dari dalam kendaraan bermotor. Hal ini dilakukan untuk bisa merasakan rasa panca indera suasana berjalan kaki di sepanjang segmen. Tabel 1 memberi rangkuman mengenai kondisi fisik spasial setiap segmen, mulai dari informasi dimensi jalur pedestrian, jarak tempuh, fungsi-fungsi dalam segmen, serta aktivitas yang terjadi di dalam segmen.
Halte TOD Dalam Koridor Jalan Riau Dalam pengamatan kawasan studi, terdapat dua buah halte, yang berjarak sekitar 500 meter satu dengan yang lain. Dengan jarak demikian, maka halte tersebut bisa dikatakan accessible, karena ada dalam jarak jalan (walking distance) maksimum sejauh 600 meter dari titik manapun dalam koridor.

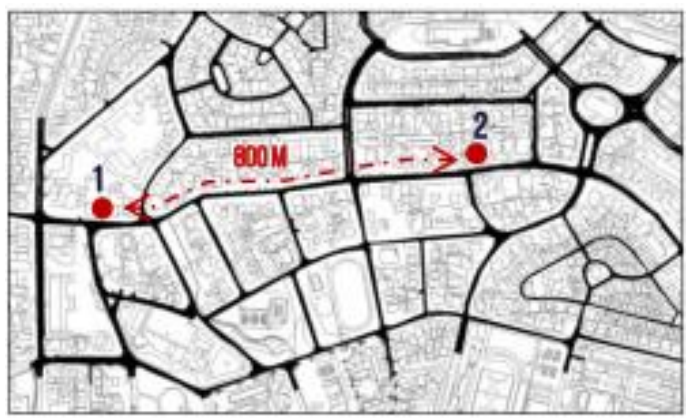

Gambar 8. Peta lokasi halte di sebelah Timur dan Barat dalam koridor jalan Riau Bandung Sumber: Dok. Pribadi pada 1 November 2016

\section{Metode Pembahasan}

Pembahasan dimulai dengan pengamatan kualitas spatial melalui sketsa dan penggambaran visual kondisi jalur pedestrian, dalam konteks mewadahi gerak aktif di dalam kawasan. Dari pengamatan dan penggambaran tersebut, dilakukan penelusuran dengan perspektif SWOT (Strenght, Weakness, Opportunity, Threat), untuk memudahkan kita melihat apa yang sedang terjadi di dalam kawasan secara spatial. Bersamaan dengan itu, dilakukan studi literatur mengenai bagaimana sebaiknya membuat jalur pedestrian yang mewadahi active living dalam kawasan kegiatan komersial.

Analisa kondisi eksisting dan studi literatur menghasilkan pedomanpedoman yang dapat digunakan sebagai 
landasan untuk membuat alternatif desain. Usulan alternatif desain dibuat dengan tema dan digambarkan dengan bentuk yang menyesuaikan kondisi eksisting.

\section{Hasil dan Pembahasan}

\section{Fungsi Perbelanjaan Dalam Kawasan Sebagai Generator Gerak}

Koridor jalan Riau ini merupakan lokasi dari beberapa fungsi penting. Dalam koridor jalan Riau sendiri, terdapat kawasan busana Factory Outlet, sarana Pendidikan, Hotel, Rumah Sakit (RS Limijati dan RS Halmahera),serta fungsi - fungsi lain yang dapat menjadi berpotensi menjadi pusat keramaian dan aktivitas.

Beraneka fungsi berarti mendatangkan beragam jenis pengunjung kawasan, sehingga kawasan ini berpotensi diisi oleh banyak macam aktivitas. Jarak yang walkable antar fungsi dalam koridor jalan berpotensi diolah menjadi suatu rangkaian perjalanan.

Terdapat beberapa fungsi yang dapat menjadi tujuan utama di dalam kawasan. Fungsi-fungsi ini dapat dijangkau dengan berjalan kaki dari satu titik ke titik lain, ditunjang oleh jalur pedestrian. Fungsi-fungsi tersebut antara lain: Riau Junction (1), Heritage - Cascade Factory Outlet (2), Stamp Factory Outlet (3), dan Kentucky Fried Chicken (4). Fungsi-fungsi tersebut berpotensi menjadi simpul berjalan kaki karena meiliki walking distances yang memadai secara linear.

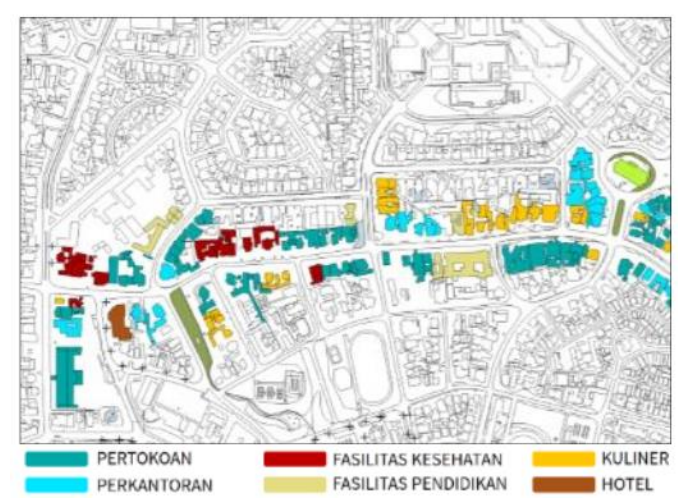

Gambar 9. Peta persebaran fungsi-fungsi di dalam koridor jalan Riau

Sumber: Dok. Pribadi pada 1 November 2016

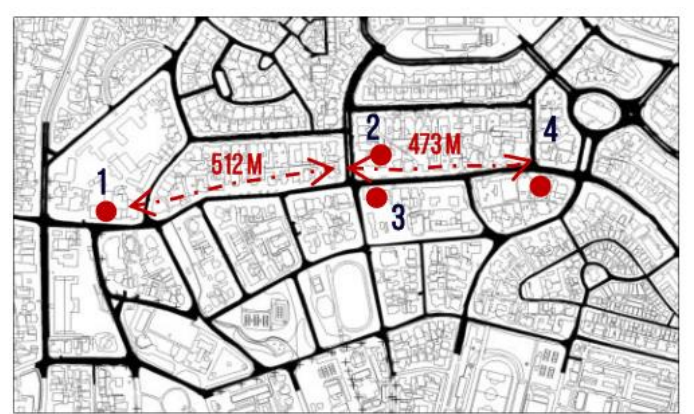

Gambar 10. Jarak antar simpul dalam kawasan studi

Sumber: Dok. Pribadi pada 1 November 2016

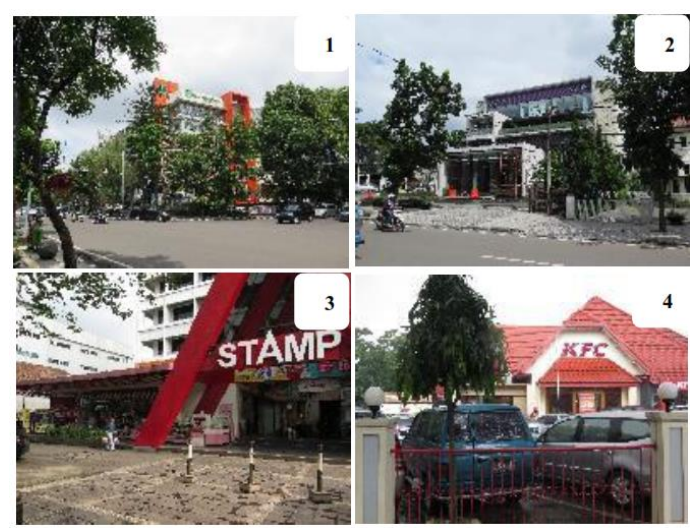

Gambar 11. Beberapa contoh fungsi-fungsi yang menjadi tujuan di dalam koridor jalan Riau

Sumber: Dok. Pribadi pada 1 November 2016 
Tabel 1. Kondisi jalur pedestrian: gambaran fisik tiap segmen dalam koridor jl. L. L. R. E Martadinata (jalan Riau)

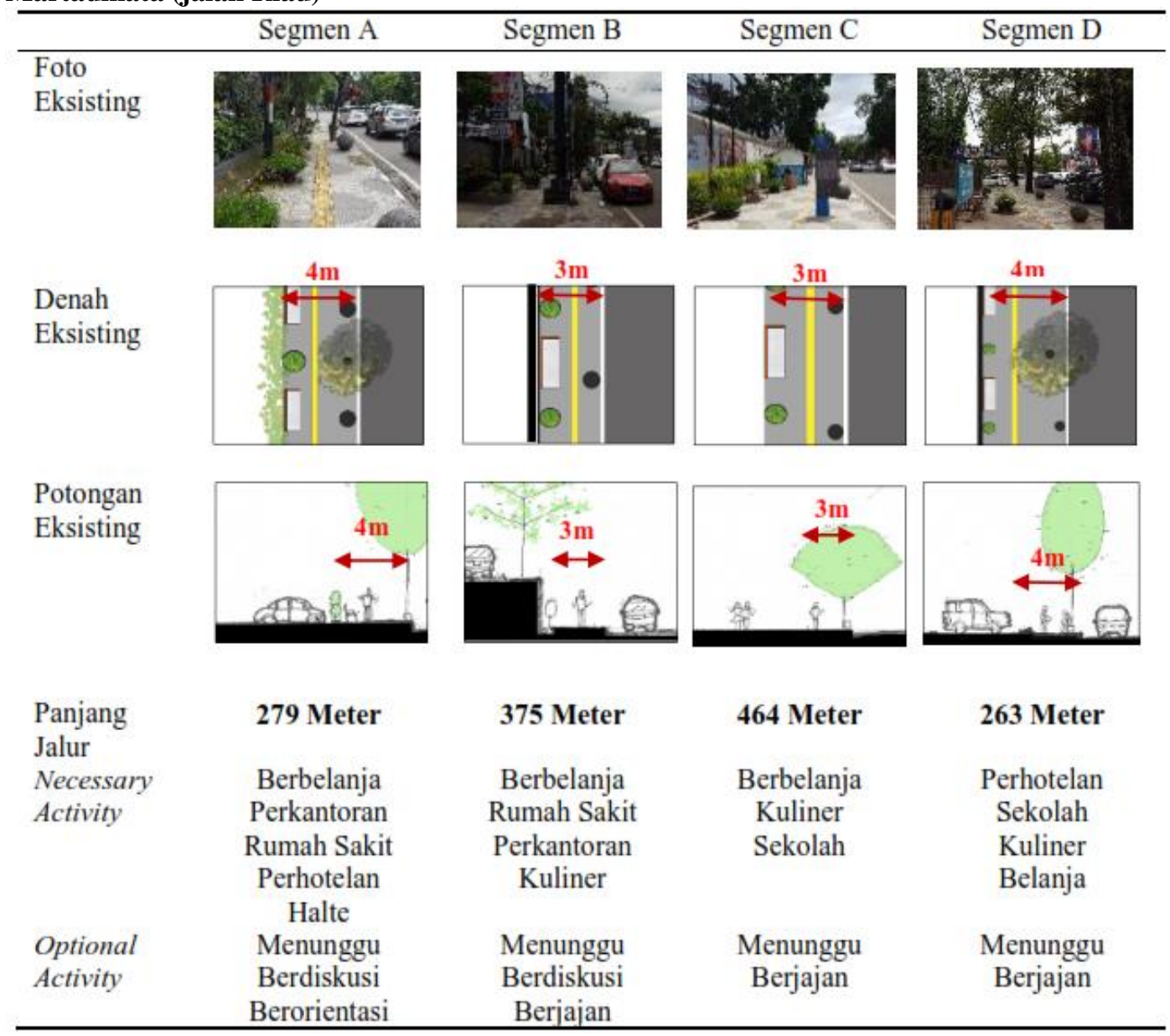

Sumber: Dok. Pribadi pada 1 November 2016

Perjalanan dengan berjalan kaki tentu saja tidak selalu memiliki jalur linear.

Maka dari itu, jarak yang ditempuh bisa saja melebihi walkabilitas dari pejalan kaki. Koridor jalan Riau memiliki kursikursi untuk mendukung aktivitas berjalan kaki seperti beristirahat atau menunggu. Terdapat dua jenis kursi yang terdapat pada jalan Riau, yaitu kursi dengan kapasitas satu orang dan kursi dengan kapasitas dua orang atau lebih. Kursi untuk satu kapasitas terbuat dari material beton, tanpa sandaran sehingga memiliki arah duduk 270 derajat. Kursi ini dipasang permanen, sehingga tidak memungkinkan untuk digeser atau didekatkan satu dengan yang lainnya. Kursi dengan kapasitas dua orang atau lebih memiliki dua tipe material, pertama campuran besi-kayu dan kedua material beton. Kursi dengan kapasitas dua orang hanya memiliki 1 arah duduk, tergantung dari posisi dan arah perletakkan kursi. Kursi dengan satu arah ini memiliki kekurangan karena tidak memungkinkan interaksi berbicara saling berhadapan. 


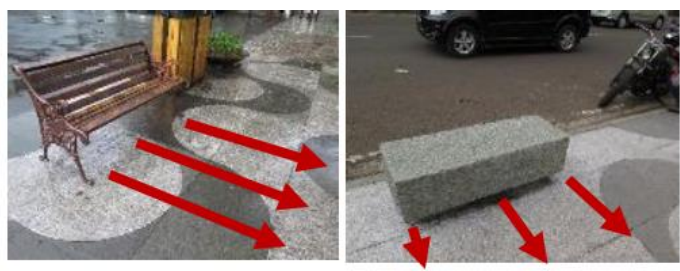

Gambar 12. Kursi dengan kapasitas dua orang atau lebih hanya memiliki satu arah hadap, tanpa percakapan muka denga muka Sumber: Dok. Pribadi pada 1 November 2016

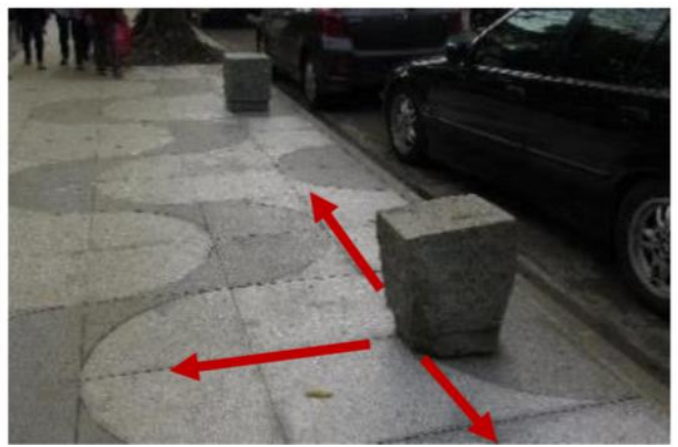

Gambar 13. Kursi dengan kapasitas 1 orang memiliki arah hadap 270 derajat

Sumber: Dok. Pribadi pada 1 November 2016

\section{Inkonsistensi Jalur Pedestrian}

Berdasarkan pengamatan segmensegmen yang ada di dalam koridor jalan Riau (tabel 1), lebar jalur pedestrian tidak memiliki ukuran yang konsisten.

Lebar yang tidak konsisten ini membuat pejalan kaki harus beradaptasi setiap berpindah segmen, sehingga mengurangi kenyamanan gerak jalan. Perbedaan lebar jalan ini juga berdampak terhadap kesatuan kawasan secara visual.

Pepohonan dapat berguna sebagai peneduh bagi pejalan kaki dan pemberi datum visual yang menyatukan kawasan di dalam koridor Jalan Riau. Titik pepohonan harus ditata sedemikian rupa sehingga rangkaian pepohonan dapat memberikan pengalaman ini. Berdasarkan pengamatan, titik vegetasi tidak memiliki perletakkan yang konsisten. Hal ini berdampak pada pengalaman berjalan kaki, dimana pada titik tertentu terik matahari menjadi tidak nyaman dan mengganggu pengalaman berjalan kaki.

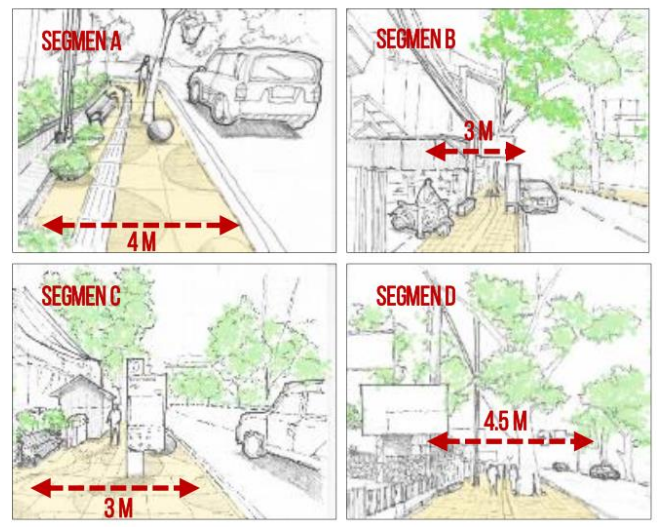

Gambar 14. Kursi dengan kapasitas dua orang atau lebih hanya memiliki satu arah hadap tanpa percakapan muka dengan muka Sumber: Dok. Pribadi pada 1 November 2016

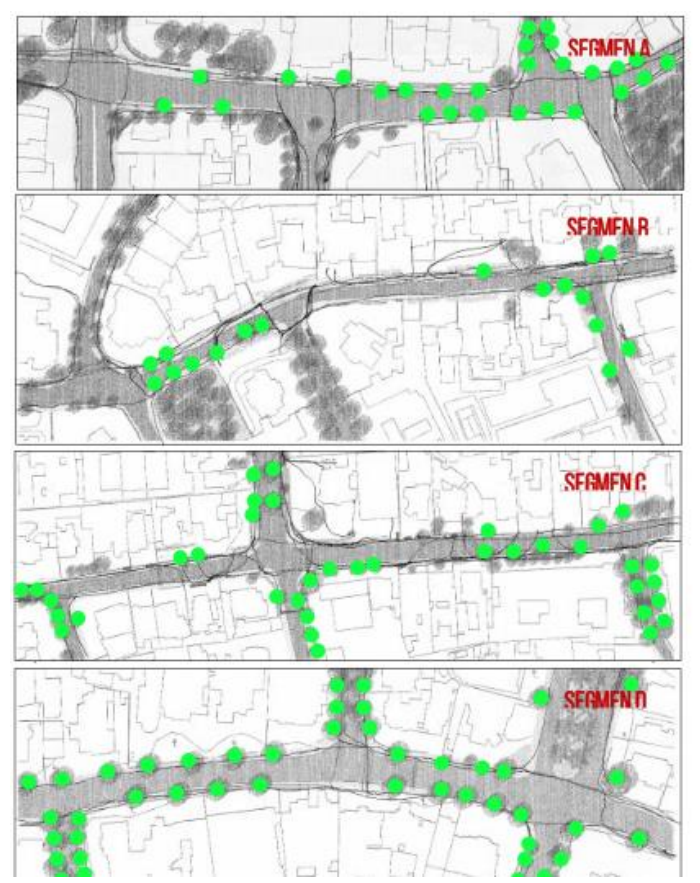

Gambar 15. Denah titik perletakkan pohon peneduh dalam segmen $A, B, C$, dan $D$ (titik hijau). Segmen A, B, dan $C$ memiliki ruangruang yang tidak memiliki pohon peneduh Sumber: Dok. Pribadi pada 1 November 2016 


\section{Pengolahan TOD untuk Pejalan Kaki}

Moda transportasi yang tersedia dalam koridor jalan Riau adalah angkutan kota (angkot). Moda trasnportasi angkot ini bisa berhenti di mana saja dalam koridor jalan, sebuah keuntungan bagi penumpang, namun akan lebih optimal lagi apabila angkutan kota memiliki tempat berhenti khusus, sehingga memaksa pejalan kaki untuk bergerak aktif.

Setiap angkutan umum disediakan dua buah halte, yang terdapat pada kawasan berjarak sekitar 800 meter satu dengan yang lain. Dengan jarak demikian, maka halte tersebut bisa dikatakan belum accessible, karena ada dalam jarak jalan (walking distance) maksimum sejauh 600 meter dari titik manapun dalam koridor. Selain itu, halte hanya tersedia dalam satu sisi lajur jalan, tidak ada halte yang melayani lajur arus balik di seberangnya. Hal ini belum menunjang sistem TOD karena tidak memberi akses bagi pejalan kaki di jalur pedestrian seberang untuk mendapatkan angkutan umum dengan halte.

Di sekitar kawasan, terdapat titik perhentian yang berada di Jalan Merdeka (titik merah pada gambar di atas). Pada titik ini, kenyamanan lebar jalur pedestrian dikurangi untuk lokasi kendaraan umum seperti bus untuk berhenti. Hal ini tidak baik untuk kontinuitas pejalan kaki, karena mengganggu dan membahayakan proses berjalan kaki.

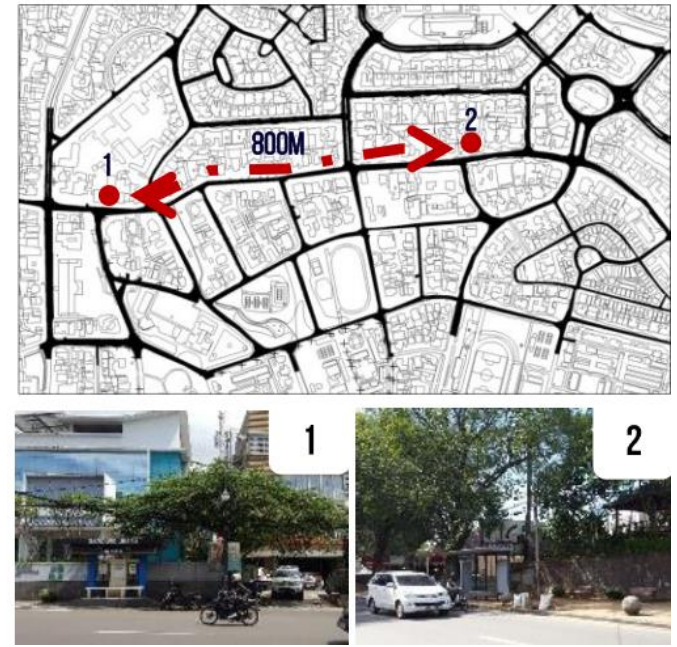

Gambar 16. Lokasi dan kondisi halte dalam koridor jalan Riau

Sumber: Dok. Pribadi pada 1 November 2016

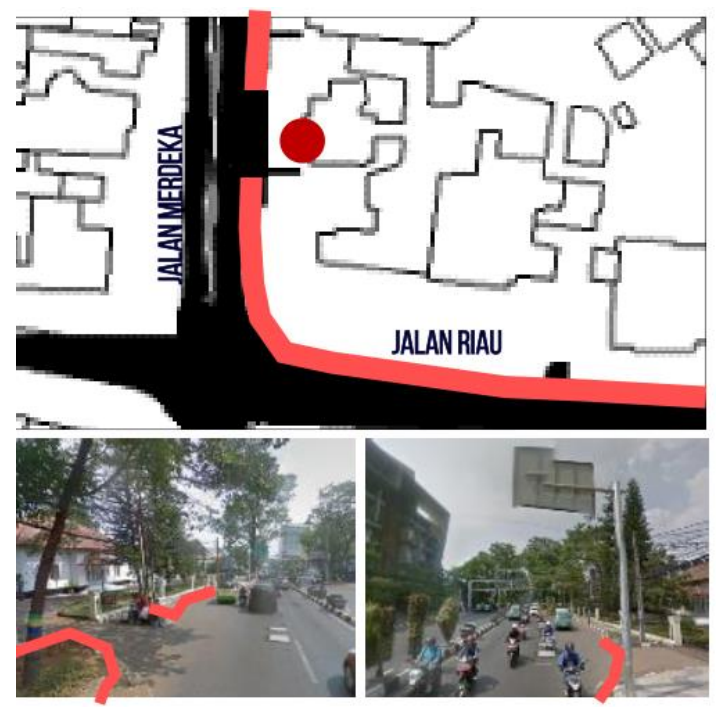

Gambar 17. Lokasi titik perhentian di jalan Merdeka memutus pedestrian

Sumber: Dok. Pribadi pada 1 November 2016

Sementara itu, halte yang ada di dalam kawasan belum memenuhi syarat halte yang baik. Halte tidak memiliki zona perhentian khusus untuk kendaraan umum. Akibatnya, kendaraan umum yang berhenti menghalangi laju kendaraan lain di belakangnya. Selain itu, posisi halte menghalangi jalur berjalan kaki, sehingga pejalan kaki harus keluar dari jalur pedestrian untuk 
melewati titik ini. Keluar dari jalur pedestrian berarti membahayakan keselamatan pejalan kaki.

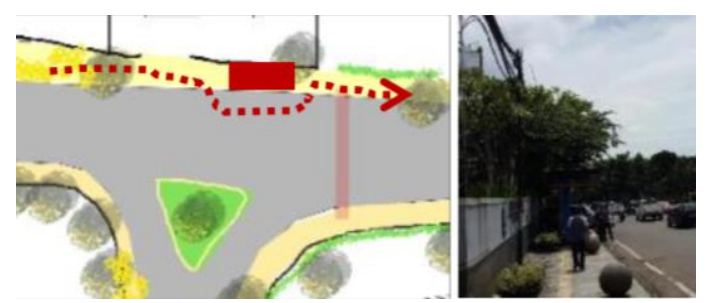

Gambar 18. Lokasi halte 1 pada segmen A, menghalagi kontinuitas berjalan kaki

Sumber: Dok. Pribadi pada 1 November 2016
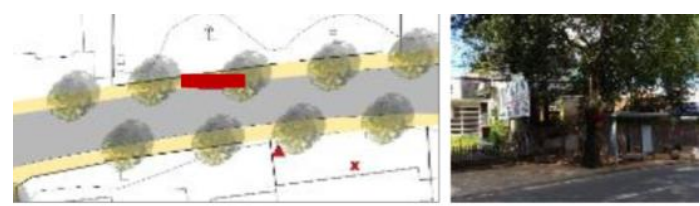

Gambar 19. Lokasi halte 2 pada segmen $D$, memiliki ruang khusus untuk kendaraan Sumber: Dok. Pribadi pada 1 November 2016

\section{Halangan Fisik dan Visual Dalam Jalur Pedestrian.}

Jalur pedestrian memiliki halangan fisik dan spasial yang mengganggu perjalanan pejalan kaki. Halangan ini berupa street furniture atau sarana utilitas ruang jalan seperti tiang listrik atau tiang telepon.

Halangan-halangan ini membuat proses berjalan kaki menjadi tidak nyaman, karena pejalan kaki harus selalu waspada terhadap halangan yang ada di sekitarnya.

Selain itu, terdapat pula halangan visual yang berupa papan iklan atau sarana utilitas. Halangan visual ini menghalangi bangunan dan pertokoan sehinga menyulitkan pejalan kaki untuk berorientasi di dalam kawasan. Selain itu halangan menghalangi kesatuan visual dan skyline dari koridor jalan.

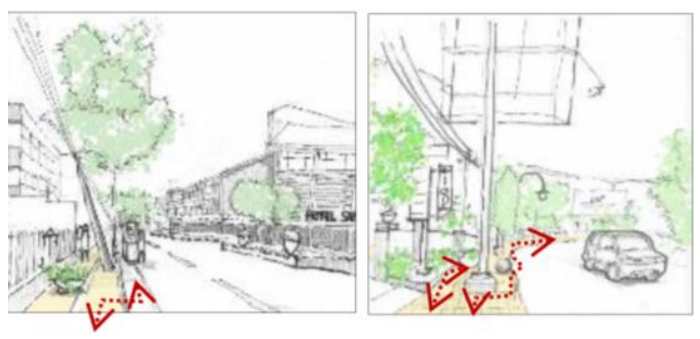

Gambar 20. Contoh halangan fisik pada segmen A (kiri) dan segmen B (kanan)

Sumber: Dok. Pribadi pada 1 November 2016

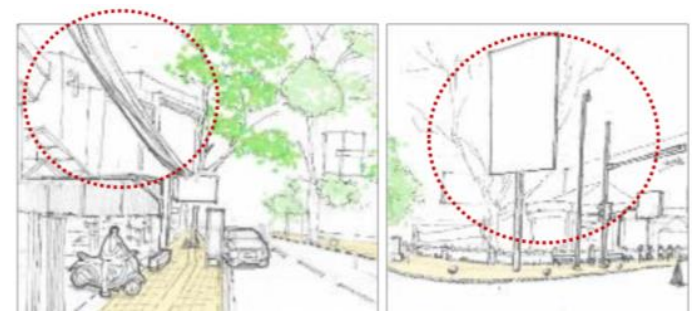

Gambar 21. Contoh halangan fisik pada segmen B (kiri) dan segmen C (kanan)

Sumber: Dok. Pribadi pada 1 November 2016

\section{Buffer Zone}

Saat ini belum terdapat pelindung khusus berupa buffer zone bagi jalur pedestrian terhadap lajur kendaraan. Hal ini mengurangi kenyamanan bagi pejalan kaki karena mereka harus mewaspadai lajur kendaraan setiap waktu jika ada kendaraan yang ugalugalan atau menerobos jalur pedestrian.

Satu-satunya segmen yang memiliki buffer zone Segmen B memiliki area parkir samping jalan. Secara tidak langsung area ini dapat berfungsi sebagai buffer zone.

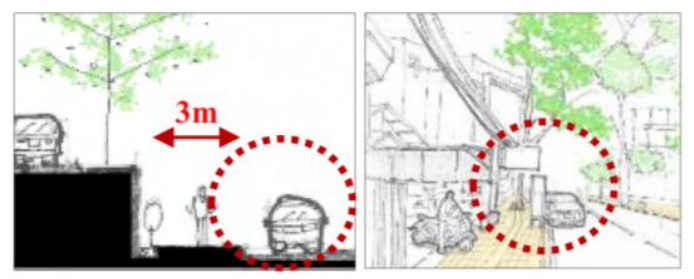

Gambar 22. Potongan buffer zone pada segmen B (kiri) dan perspektif (kanan)

Sumber: Dok. Pribadi pada 1 November 2016 
Buffer zone seharusnya terdapat pada sisi pertemuan antara jalur pedestrian dengan jalur kendaraan bermotor, melindungi pejalan kaki dan aktivitas dalam jalur pedestrian.

\section{Persinggungan Dengan Kendaraan Bermotor.}

Lajur Pedestrian Through Zone kerap terpotong oleh ramp masuk kendaraan bermotor, sehingga kontinuitas level berjalan kaki menjadi tidak konsisten. Hal ini berdampak pada proses dan kenyamanan berjalan kaki sepanjang koridor jalan Riau. Jalur Pedestrian Through Zone sebaiknya tidak terpotong oleh ramp kendaraan. Pemotongan jalur menjadi ramp sebaiknya terjadi dalam curb zone.
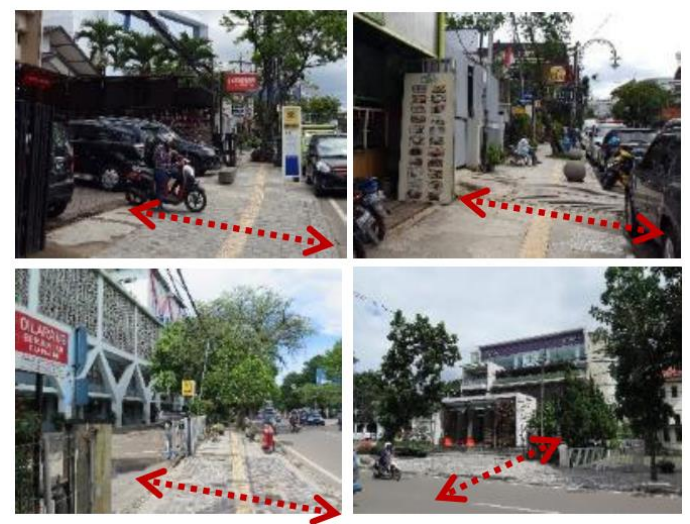

Gambar 23. Jalur pedestrian dipotong untuk ramp naik kendaraan bermotor menuju kavling, mengurangi kenyamanan berjalan kaki

Sumber: Dok. Pribadi pada 1 November 2016

\section{Pedoman Perancangan Jalur}

\section{Pedestrian}

Berdasarkan analisis kawasan secara spesifik, maka terdapat beberapa kriteria yang harus dipenuhi dalam perancangan jalur pedestrian di koridor jalan L. L. R. E. Martadinata Bandung, yaitu:

a. Jalur pedestrian memiliki lebar yang konsisten; b. Jalur pedestrian memiliki pembagian zona yang konsisten bagi jalur pejalan kaki dan street furniture;

c. Jalur pedestrian menyediakan kursi untuk beristirahat, baik kursi untuk sendiri maupun kursi untuk percakapan;

d. Jalur pedestrian bebas dari halangan fisik, seperti utilitas jalan atau tiang iklan;

e. Ramp kendaraan menuju kavling tidak memotong lajur jalan pejalan kaki.

\section{Pedoman Perancangan Halte TOD}

Berdasarkan analisis kawasan secara spesifik, maka terdapat beberapa kriteria yang harus dipenuhi dalam perancangan halte TOD di koridor jalan L. L. R. E. Martadinata Bandung, yaitu:

a. Halte memiliki ruang henti khusus bagi kendaraan umum;

b. Halte mewadahi optional activities dari menunggu kendaraan umum;

c. Halte terletak dekat dengan pintu masuk fungsi penting;

d. Halte tidak memotong jalur pedestrian.

\section{Usulan Tema Perancangan}

Tema perancangan yang diambil yaitu active stroll shopping street corridor, dimana pengunjung berbelanja melalui gerak aktif sepanjang jalur pedestrian. Jalur pedestrian ini mewadahi optional activities dari proses berbelanja, sedangkan kavling bangunan melayani necessary activities, yaitu berbelanja.

\section{Usulan Konsep Desain Jalur \\ Pedestrian}

Dalam gagasan, jalur pedestrian dibuat selebar 4.5 meter, yang terbagi menjadi 3 bagian. Bagian ini berupa buffer zone 
untuk melindungi pejalan kaki dari jalur kendaraan bermotor dan datum bagi jalur pedestrian, curb zone sebagai ruang untuk menyimpan street furniture, pedestrian through zone sebagai ruang lalu lalang bebas pejalan kaki. Motif finishing material dari jalur pedestrian dibuat berselang-seling merah dan putih, dengan konsep meningkatkan awareness akan keberadaan jalur pedestrian. Warna merah terbuat dari granit merah yang dibakar, dipilih karena merupakan warna yang dominan dan menonjol. Warna putih terbuat dari granit yang dibakar dipilih sebagai penunjang warna merah. Pepohonan eksisting dibiarkan tetap berada dalam jalur pedestrian, sedangkan pepohonan baru ditambahkan untuk memberi konsistensi keteduhan dan datum visual.

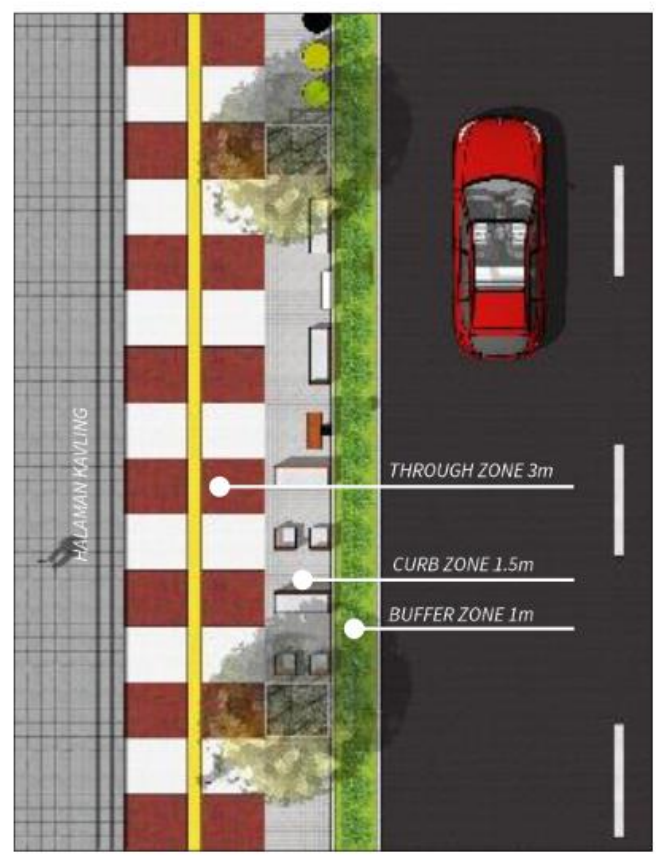

Gambar 24. Denah gagasan jalur pedestrian Sumber: Dok. Pribadi pada 1 November 2016
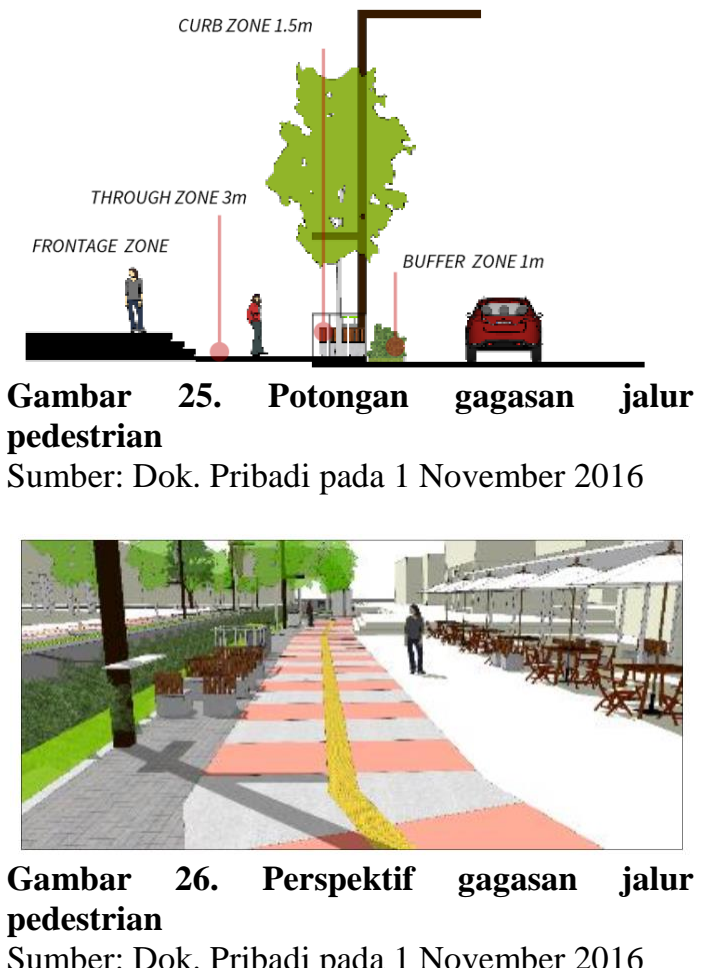

\section{Halte TOD}

Pada Segmen A, terdapat halte transit untuk moda angkutan umum. Halte ini terletak di seberang persimpngan jalan antara jalan Riau dengan jalan Sumatera, kemudian dekat dengan Riau Junction sebagai titik pusat aktivitas pada segmen ini.

Gagasan halte baru diletakkan di depan pintu masuk Riau Junction, supaya dekat dengan titik pusat keramaian dan lebih mudah dijangkau. Gagasan halte ini memanfaatkan sebagian dari halaman Riau Junction untuk memberi ruang bagi jalur perhentian kendaraan umum. Halte ini terletak dalam curb zone, sehingga tidak menghalangi lajur pejalan kaki. 


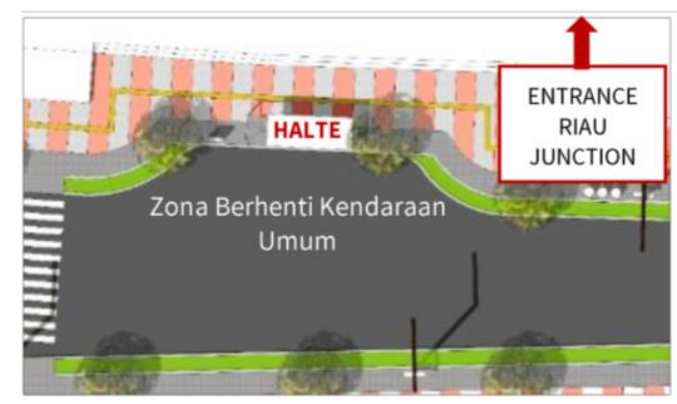

Gambar 27. Rencana blok gagasan halte untuk segmen A

Sumber: Dok. Pribadi pada 1 November 2016

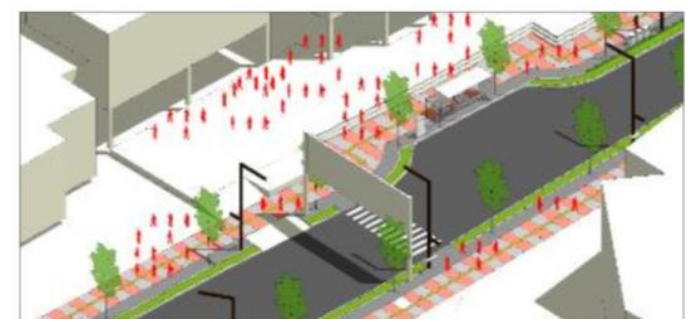

Gambar 28. Isometri gagasan halte untuk segmen A

Sumber: Dok. Pribadi pada 1 November 2016

Pada Segmen D, terdapat halte transit untuk moda angkutan umum. Halte ini terletak di Jalan Riau, kemudian dekat dengan Sekolah Taruna Bakti yang juga ramai dengan aktivitas. Halte ini belum memenuhi syarat halte yang baik. Halte tidak memiliki zona perhentian khusus untuk kendaraan umum, akibatnya, kendaraan umum yang berhenti menghalangi laju kendaraan lain di belakangnya. Halte juga belum memberi optional activities yang memadai, karena hanya memberi aktivitas menunggu berupa duduk saja. Gagasan halte baru diletakkan di seberang halte yang ada saat ini, untuk mengakomodir arus balik dari halte di Riau Junction. Gagasan halte ini memanfaatkan sebagian dari plaza Hotel Pavilioen untuk memberi ruang bagi jalur perhentian kendaraan umum. Halte ini terletak dalam curb zone, sehingga tidak menghalangi lajur pejalan kaki.

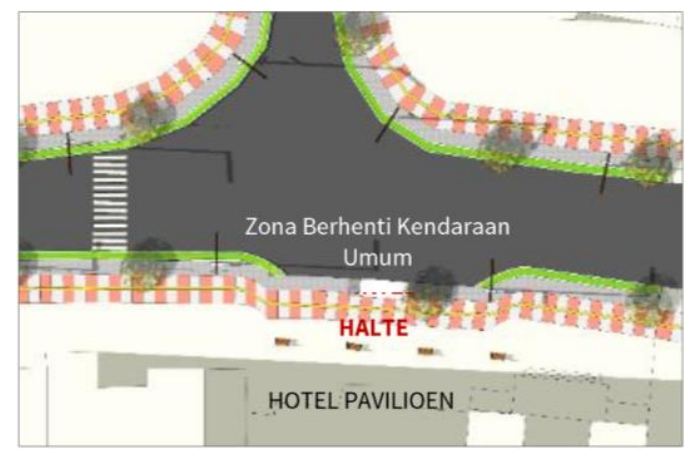

Gambar 29. Rencana blok gagasan halte untuk segmen D

Sumber: Dok. Pribadi pada 1 November 2016

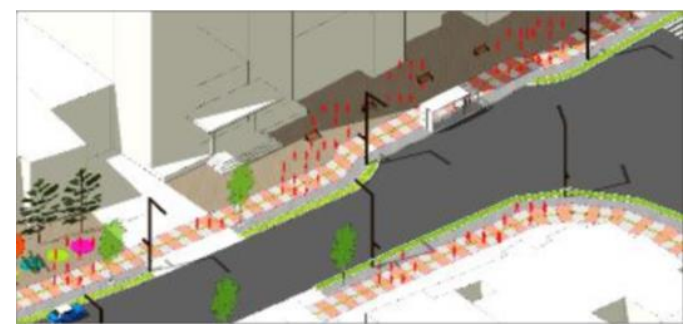

Gambar 30. Isometri blok gagasan halte untuk segmen D

Sumber: Dok. Pribadi pada 1 November 2016

Gagasan halte mewadahi kegiatan menunggu kendaraan umum dengan cara berbeda. Selain menunggu, terdapat optional activities lain yang membuat pengalaman menunggu menjadi tidak membosankan. Optional activities ini berupa ayunan gantung yang bisa dipakai anak-anak maupun orang dewasa. Bentuk halte dibuat sederhana dengan warna putih yang menjadi kontras dengan finishing permukaan lantai dan suasana keramaian sekitar. Halte ini terletak di ujung jalur pedestrian sehingga tidak mengganggu jalur pejalan kaki dan jalur penyandang cacat. 


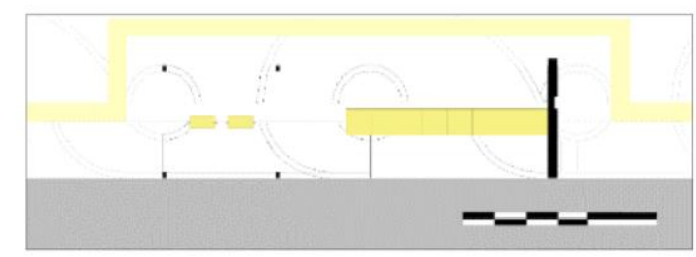

Gambar 31. Denah gagasan halte tipikal Sumber: Dok. Pribadi pada 1 November 2016

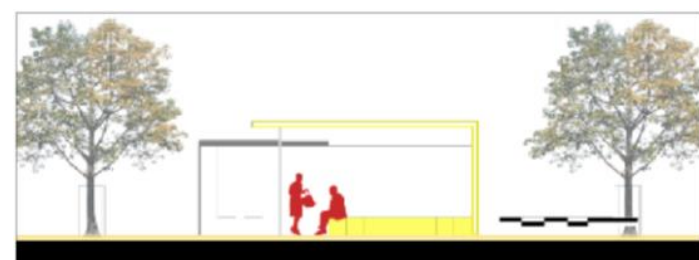

Gambar 32. Potongan gagasan halte tipikal Sumber: Dok. Pribadi pada 1 November 2016

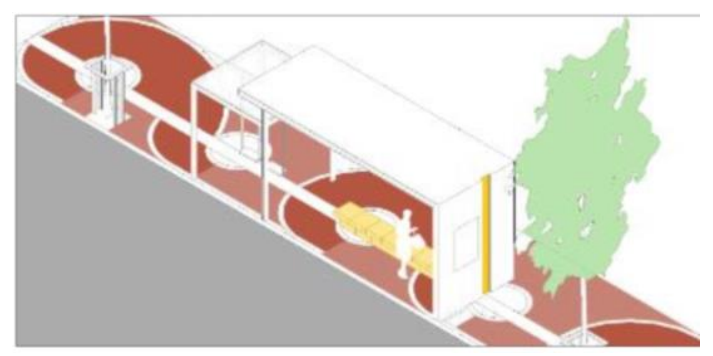

Gambar 33. Isometri gagasan halte tipikal Sumber: Dok. Pribadi pada 1 November 2016

\section{Kesimpulan}

Dalam pengamatan, didapati bahwa jalur pedestrian dalam kawasan belanja jalan L. L. R. E. Martadinata belum sepenuhnya mewadahi gerak aktif dalam jalur pedestrian. Terdapat value active living yang hilang karena inkonsistensi lebar jalan, elemenelemen fisik dan spatial yang mengganggu proses berjalan kaki serta persinggungan dengan kendaraan bermotor yang membuat pengalaman berjalan kaki menjadi tidak nyaman. Penduduk kota tentu tidak nyaman untuk bergerak aktif melalui jalur pedestrian. Berdasarkan analisa, maka dibuat pedoman mengenai jalur pedestrian yang sepenuhnya mewadahi gerak aktif, membawa kembali value active living yang hilang karena wadah gerak aktif yang kurang memadai. Usulan alternatif desain diberikan untuk memberi gambaran mengenai proses berjalan kaki yang nyaman dan optimal.

\section{Daftar Pustaka}

Centers for Disease Control and Prevention. Surgeon General's Report on physical activity and health. JAMA 1996;276(7):522.

City of New York. (2013). Active Design, Shaping the Sidewalk Experience. City of New York Publishing. New York.

City of New York. (2013). Active Design Guidelines, Promoting Phyisical Activity and Health in Design. City of New York Publishing. New York.

Charlier, Jim. (2009). Pedestrian and The City: Planning and Design for Humans. Houston Tomorrow. Texas

Curran, Raymond J, (1983). Architecture and The Urban Experience, Van Nostrand Reinhold Co.: New York

Danisworo, (1991). Teori Perancangan Urban, Bandung, Fakultas Pascasarjana, ITB.

DeBourdeaudhuij ID, Sallis JF, Saelens B. (2003). Environmental correlates of physical activity in a sample of Belgian adults. American Journal of Health Promotion.;18(1): p. 83-92.

Farr, Douglas. (2008). Sustainable Urbanism: Urban Design with Nature, Wiley Publishings: New Jersey

Gehl, Jan. (2010). Cities for People. Island Press. Washington DC

Jacobs, Allan. (1995). Great Streets. MIT Press. New York 
Jacobs, Jane, (1961), The Death and Life of Great American Cities, Random House.: New York

National Association of City Transportation Officials. (2013). Urban Street Design Guide, NACTO publications: New York.

Parks and Recreation. (Mar 2003), 38, 3; ProQuest Research Library hal 48. 
Jurnal Teknik Arsitektur ARTEKS, Volume. 2, Nomor 1, Desember 2017 